\title{
VALUATION OF SECURITY INTERESTS UPON EXPROPRIATION
}

\author{
FRANCIS C. R. PRICE*
}

\begin{abstract}
With the introduction of The Expropriation Act, S.A. 1974, c. 27, Alberta became and today remains the only jurisdiction in Canada where security interests are valued upon expropriation on the basis of their market value. The other Canadian jurisdictions compensate security holders on the basis of the outstanding balance owed on their security. In this article a brief review of the relevant Ontario provisions is made, and the article discusses the difference between the Alberta and Ontario provisions, analyzing the advantages and disadvantages of each approach, and in particular reviewing the potential problems which may result from the approach adopted by the Alberta Expropriation Act.
\end{abstract}

\section{HISTORY}

Prior to the enactment of The Expropriation Act, S.A. 1974, c. 27 , on July 9,1974 , the method of valuing a security holder's interest in the property being expropriated was straightforward. The land itself was valued in the normal fashion, as if unencumbered. The security holders ${ }^{1}$ would then receive the principal and any interest owing in accordance with the priority of their particular security against the title. This type of approach will be referred to as "the outstanding balance" approach. Such an approach has the most apparent benefit of simplicity. However, as will be seen below, such a system contains many possible inequities affecting both the mortgagor and the mortgagee.

The 1960's witnessed significant new developments in expropriation legislation at both the federal and provincial levels. The Law Reform Commissions of Ontario, British Columbia and Canada together with the Institute of Law Research and Reform of Alberta ${ }^{2}$ produced reports containing detailed analyses of existing expropriation provisions together with recommendations for new expropriation legislation. With the exception of the report of the Ontario Law Reform Commission, these reports recommended the valuation of mortgages using the market value approach, i.e. the separate valuation of the mortgage according to its market value, as distinct from the amount owed thereon. Despite these recommendations, the federal Expropriation Act contains provisions ensuring the valuation of mortgages on the outstanding balance method, while British Columbia has still not enacted new expropriation legislation at all. As a result, following the Report of the Institute of Law Research and Reform, Alberta became, and still remains, the only jurisdiction to value mortgages on a market value approach.

* LL. B. (Hons.) (Melb.), LI.M. (Alta.), with the firm of Reynolds, Agrios \& Mirth, Barristers and Solicitors, Edmonton, Alberta.

1. In this paper, relerence will be made only to "mortgage", "mortgagee" and "mort. gagor". However, the principles and comments relating to mortgages apply as well, to agreements for sale and other security interests.

2. Ontario Law Reform Commission, The Basis for Compensation on Expropriation. (1967). The Royal Commission Inquiry into Civil Rights (The McRuer Report) (1968). British Columbia Law Reform Commission, Report on Expropriation, (1971). Law Reform Commission of Canada, Expropriation, (1976). Alberta Institute of Law Research and Reform, Report No. 12, Expropriation, (1973). 
Sections 47 and 50 of The Expropriation Act (Appendices A and B respectively) are the two sections which deal with the valuation of and compensation for mortgages and other security interests. The value of the interest of each person in the land, whether by way of mortgage, other security interest or otherwise, is established separately, and compensation is paid on the basis of the market value of that particular interest in accordance with the provisions of s. 40.

\section{COMPARISON OF APPROACHES}

Ontario's legislation contains provisions which provide an outstanding balance approach with some modifications and exceptions designed to overcome the inequities of the old 'outstanding balance' method of compensation. This paper will make a brief review of the approach followed in the Ontario legislation and to this end the relevant sections of the Ontario Expropriations Act3 (Sections 17 and 20) are included as Appendix C.

\section{A. Ontario - Outstanding Balance Approach}

Section $17(2)(b)$ sets out the approach to compensation of a security holder's interest. The market value of the land is ascertained on the basis that the land is unencumbered. To this sum is added any amount awarded by way of damages for injurious affection. This total amount is then substituted for the land and it is against this amount that mortgagees may make their claim for compensation, subject to the remaining subsections of $s .17$. Out of the amount awarded for market value and damages, payment is made to the mortgages and other security holders in accordance with their priority on title. They are paid the full amount of principal and interest outstanding (whether or not the same is yet due). Section 20 provides for certain other payments and/or compensation to the mortgagee and to the mortgagor in circumstances where a straight application of the outstanding balance approach would be clearly inequitable to either party. These situations include the payment to the mortgagee of a bonus in respect of the prepayment by the expropriating authority, together with compensation to either the mortgagee or the mortgagor, as the case may be, for damages resulting from the existence of lower or higher interest rates following the expropriation. More detailed consideration of these provisions is reserved for the portion of this paper dealing with the outstanding balance method.

\section{B. Alberta - Market Value Approach - Section 47}

Before reviewing the effect of $s .47$ upon the calculation of compensation payable to security interest holders, some comments must be directed towards the interpretation of s. 47 itself. Unfortunately, the wording of the section is far from clear in attempting to convey the intention of the legislature. Section $47(1)$ refers to the "market value of each person". Clearly this cannot mean that the Land Compensation Board is required to calculate the value of the shares of a particular mortgage company, or the net worth of an individual mortgagee. 
However, the problem arises as to whether the interest to be valued is the interest of the security holder in the land or alternatively, the market value of the whole security held by the lender. When subsections (2) and (3) of s. 47 are analysed, the intention of the Legislature becomes more obscure. Under $47(2)$ the payment to a security holder of the market value of his security will effect complete satisfaction and payment of the "security interest", where there is no collateral security other than the covenant of the borrower to pay the money. Section 47(3), on the other hand, refers to situations where the security holder has also obtained collateral security from the borrower. In these cases, the compensation paid upon expropriation "shall not fully discharge the debt", and The Land Compensation Board is to determine the balance outstanding and how it is to be repaid.

The problem arises because of the different wording used in subsections (2) and (3) of s. 47. In both situations to which s. 47(2) and (3) apply, the market value of the security (the compensation) must be paid by the expropriating authority. Upon payment, s. 47(2) provides for full satisfaction of "the security interest" where there is no collateral security. However, where there is collateral security, s. 47(3) refers to the compensation "not fully discharg(ing) the debt". As a result, it is not altogether clear whether what is discharged is the total debt from the borrower to the lender or only the security against the land itself.

Clearly the provisions of The Judicature Act will determine the above problem insofar as mortgages governed by that Act are concerned. However, the success or failure of the market value approach in its attempt to deal with the problem of debt discharge in other circumstances will be reviewed below.

\section{OUTSTANDING BALANCE APPROACH}

The outstanding balance approach is presently used in all jurisdictions in Canada, with the exception of Alberta.

Despite the strong recommendations of the British Columbia Law Reform Commission 4 and the Law Reform Commission of Canada ${ }^{5}$ that the market value approach be adopted for the calculation of compensation for mortgages, neither British Columbia nor the Federal Government have yet amended the legislation to introduce such an approach.

The outstanding balance method has already been described by way of reference to the provisions of the Ontario Expropriations Act (s. $17(2)(b)$ - appendix C).

In Ontario the market value of the land plus any damages for injurious affection will represent the expropriated interest in the land for the purposes of payment to the mortgagees. However under s. 28 of the Federal Expropriation Act this sum will include general disturbance damages and where appropriate additional costs of reinstatement or additional costs awarded under the home-for-home provision

4. B.C. Law Reform Commission, Report on Expropriation, (1971) at 140-141.

5. Law Reform Commission of Canada, Expropriation, (1976) at 25. 
in that Act, but not damages for injurious affection. Mortgagees are then paid the principal and interest outstanding on their particular mortgages whether or not the same are due, to the extent that the value of the property, as calculated under the particular statute, will allow.

The main advantage of the outstanding balance approach is its simplicity. Mortgagors and mortgagees alike are accustomed to dealing with the outstanding balance of principal and interest. There is no need for a possibly complicated appraisal of the market value of a mortgage and any problems that might be encountered in obtaining evidence to assist in calculating the market value for a particular mortgage do not present themselves. The mortgage contract itself and the payments made thereunder, will be the only items which will determine the amount outstanding.

A further advantage seen by many mortgagees is that the outstanding balance approach, which involves (subject to satisfactory provisions relating to prepayment bonuses) the same repayment provisions as exist in connection with the remaining investments of the particular mortgagees, permits their budgeting and planning of investments to be carried out without any unnecessary complications.

However, the disadvantages of this approach are numerous. First of all, it is inflexible. It treats two mortgages, which happen to have the same amount of principal and interest outstanding, in identical fashion (assuming sufficient equity in the land expropriated), regardless of differences in interest rates, priority, term of the mortgage remaining and so on. Differences such as these provide significant variation in the actual market value of the securities that are being paid out.

Furthermore, the outstanding balance approach ignores special features of security interests such as participation or bonus mortgages. In the case of a participation mortgage, the mortgagee may have agreed to lend money at a lower interest rate than normal in exchange for a specified share in the success of the business venture in question. This "piece of the action" that the mortgagee has will not be reflected in the outstanding balance. Bonus mortgages, i.e. mortgages under which the amount secured exceeds the amount actually advanced, will include not only a case where a mortgagee receives a mortgage for an amount in excess of the amount actually lent (usually in exchange for a reduction in the nominal interest rate), but also situations involving purchase money mortgages where the purchase price of the property being sold, at an inflated price, is secured, in part, by way of a mortgage granted at favourable interest rates to offset the inflated price of the property.

Secondly, payment of the entire principal and interest owing ignores the reality of the investment entered into between the mortgagor and the mortgagee, namely, the repayment by the mortgagor and the annuity received by the mortgagee over an extended period of time. Repayment of this entire amount immediately upon expropriation will severely penalize the mortgagor who has entered into heavy financing over an extended period of time in the hope that his success in his (say) commercial venture will ensure that the financing commitments can be met in the time period over which they extend. Where such 
heavy financing was obtained at favourable rates, to place the mortgagor in the position of having to obtain substitute financing at the present (higher) interest rates available will place substantial additional strain on the mortgagor.

In situations where interest rates have dropped, forcing the mortgagee to accept immediate payment of the total principal and interest due under the mortgage contract will penalize the mortgagee in terms of the yield that it will be able to receive from its money upon reinvestment of the funds at the current (lower) rate of interest.

Even if interest rates and market conditions are identical to those contemplated at the time the mortgage was originally executed, the pure outstanding balance method will penalize the mortgagee to the extent that it may lose some time before it finds another investment project for its funds.

In Ontario, where the outstanding balance approach prevails, attempts have been made to overcome the problems arising from the outstanding balance approach as they affect the mortgagor and mortgagee. Section 20 of The Expropriations Act provides that the expropriating authority pays to the mortgagee a prepayment bonus of three months interest on the amount of principal prepaid at the rate of 6 percent per year, or the value of any prepayment bonus actually provided for in the mortgage, whichever is the lesser amount. This provision of three months interest, which follows the precedent set by Section 10 of the federal Interest Act, provides the mortgagee with compensation for the cost and inconvenience of having to reinvest his capital.

The amount paid to the mortgagee by way of bonus is not deducted from the amount finally paid to the mortgagor. It is the responsibility of the expropriating authority to bear the expense of prepayment of the mortgage. Such expense is not borne by the mortgagor. As will be seen below, s. 50 of the Alberta Expropriation Act also makes provisions for the payment of a bonus to the mortgagee by the expropriating authority.

As already discussed, a rise or fall in the interest rates applicable to the type of security being expropriated will penalize the mortgagor (rise in interest rates) or the mortagee (fall in interest rates). Subsections (b) and (c) of s. 20 of the Ontario Expropriations Act are designed to compensate the affected party in such circumstances. Under s. 20 (b), where the current interest rates are lower than the rates set out in the mortgage, and where the mortgagor is not entitled to prepay the mortgage at the date of the expropriation, the expropriating authority must pay compensation to the mortgagee based on the difference between the mortgage rate of interest and the current rates of interest during the remainder of the term of the mortgage (such period not to exceed five years).

By s. 20 (c) the expropriating authority must pay additional compensation to a mortgagor who is faced with higher interest rates, based on the difference between the interest rate as provided in the mortgage and the current rates of interest in existence on similar mortgages for the remainder of the term of the mortgage. 
An initial problem arises out of the two subsections. It will be impossible to calculate with any certainty the amount of compensation payable, unless at the time of the compensation hearing the term of the mortgage is actually expired, as it will be impossible to forecast the varying interest rates during the period of the calculation set out in subsections (b) and (c) of s. 20. R.B. Robinson, Q.C., in his Report on The Expropriations Act ${ }^{6}$ recommended simplification of this calculation by defining the "new interest rate" as the interest rate prevailing at the date of expropriation. To date, however, no such amendment has been made.

Quite apart from any problem of calculation of this compensation, it is clear that any such payment of compensation will be at the expense of the expropriating authority. In the case where interest rates have risen, the mortgagee will be paid the outstanding balance and interest in full, which it can now invest (together with any bonus paid) at the higher rate of interest and receive a higher yield on its investment than it was receiving prior to the expropriation. At the same time, the mortgagor will be paid additional compensation to offset the additional costs of obtaining new financing at the higher rate of interest. Where the interest rates have declined, it is the mortgagor who will obtain the benefit of the payment to the mortgagee, but only of the outstanding balance of principal and interest (which sum the mortgagor can now borrow at a lesser cost to himself) while the mortgagee is compensated pursuant to the terms of Section 20 (b) of the Act. This unfairness to the expropriating authority was noted by Mr. Robinson in his report,? but be concluded "this is the inevitable result of the decision not to adopt the principal of paying the market value of a security interest rather than the principal and interest outstanding".

\section{MARKET VALUE APPROACH}

As a result of the change in approach to the valuation of security interests provided in The Expropriation Act, 1974, compensation is now calculated on the basis of market value for every type of interest in land that is expropriated, whether that interest be the unencumbered fee simple, an easement, lease, mortgage or any other interest in land.

In the context of mortgages, this new approach by the legislation reflects the position that the mortgage is not just an isolated contract, but is an investment made by the mortgagee that has at all times a value to the mortgagee. This value will depend on a number of factors, such as the interest rate on the mortgage and the rate of interest on similar loans being made at the time of the expropriation, the nature of the security, additional features such as participation clauses, the length of the term remaining and so on.

Since the interest of both mortgagor and mortgagee are valued separately, neither is over-compensated at the expense of the other, nor in fact over-compensated at all. Furthermore, assuming there is

6. R.B. Robinson, Q.C., Report on The Expropriation Act (Ontario), (1974). at p. 40.

7. Id at 41 . 
no deficiency in the value of the land as security, there is no overpayment by the expropriating authority as is the case under legislation similar to that prevailing in Ontario.

As has been shown above, the outstanding balance approach requires the creation of a number of exceptions in order to treat both the mortgagor and the mortgagee equitably, although in doing this it is the expropriating authority that suffers. The use of the market value approach avoids the need for the introduction of these exceptions and to a large extent deals with the problems raised by participation mortgages, bonus mortgages, and similar special features.

In particular, the market value approach deals successfully with the problem caused by the rise or fall in interest rates, without placing additional expense upon the expropriating authority. In the case where interest rates have risen in comparison with the interest rate specified in the mortgage, the market value of the mortgage (all other things remaining the same) will be reduced as a result of the less attractive rate of interest contained in the mortgage contract. Where the mortgagee is paid this market value, it will receive a lesser sum than it would have obtained under the outstanding balance approach. However, since the rate of interest currently available for similar investments at the time of the expropriation is higher, the mortgagee will be able to receive the same yield on its new investment as it was receiving prior to the expropriation, even though its investment may be smaller in dollar amount than it was at the time it entered into the original mortgage contract.

Meanwhile, the mortgagor's equity in the property will be increased as a result of the reduced deduction from the total value of the property, and he will have additional funds from his equity in the expropriated land which will offset the additional costs of borrowing money at the date of the expropriation. The mortgagee will be paid less than under the outstanding balance approach, but will be able to invest this at the higher rate of interest and receive the same yield on its investment before and after expropriation. Finally, the expropriating authority has not been forced to over-compensate either party.

One problem that is often raised in relation to the market value approach to compensation of security interests is the availability of a "market" in order to obtain current rates of interest on comparable investments with a view to determining the market value of a particular security itself. The Alberta Institute of Law Research and Reform raised this problem for consideration in its Working Paper on the Principles of Compensation, ${ }^{8}$ but came to the final conclusion, in recommending the market value approach to compensation, that there was a "reasonably discernable market for housing mortgages", and suggested "that a market value can be reasonably imputed for any mortgage based on comparisons of current interest rates and trend with the interest rate, terms of payment, amount outstanding and soundness of the security of the particular mortgage". The same problem was raised by the British Columbia law Reform Commission, ${ }^{9}$

8. Alberta Institute of Law Research and Reform, Working Paper on the Principles of Compensation (1971) at 38.

9. British Columbia Law Reform Commission, Report on Expropriation, (1971) at 141. 
and in an appendix prepared by Professor S.W. Hamilton, to the portion of the Report dealing with the valuation of security interests, it was stated:10

"While the secondary market for mortgages is not as active as that for bonds and stocks, sufficient volume and expertise exists to resolve the problem. Most certainly, the market in. formation concerning mortgages is more readily available than the corresponding market data for real property, either fee simple or leashold estates. Several companies specialize in the purchase and the placement of mortgage contracts and could provide expert evidence, much as an appraiser produces expert evidence on real property."

In Alberta too, there exists a substantial number of mortgage placement agencies and/or brokers, so that expert evidence as to the terms and conditions of similar investments at the time of particular expropriation will be readily available. In the writer's experience, appraisers do not appear to find too many difficulties involved in obtaining market data on all types of mortgages, whether residential or commercial, small or large. In addition, where a great deal of the comparison of a particular investment will be done by way of discounting or other mathematical adjustments to available figures, much of the comparison will result from the application of certain appraisal principles rather than the application of a volume of comparable market data.

One problem, however, which will arise with the valuation of security interests on the basis of their market value will be the increased costs of ascertaining the market value of the particular security interest.

The old method of valuing a mortgage on the basis of the outstanding balance of principal and interest required little else than a statement or computer printout from the mortgage company setting out the balance owing as at a particular date. With the requirement to value a mortgage on the basis of its market value will come the need for expert evidence as to the exact value of the particular mortgage. Because s. 37(1) of the Act provides that the expropriating authority must pay all the reasonable legal, appraisal and other costs actually incurred by the owner for the purposes of determining the compensation payable, and because "owner" will include both the mortgagor and the mortgagee, the cost of appraisals of the mortgage together with the cost of witnesses at any hearing must be paid for by the expropriating authority. Where the mortgage is a small one the cost of valuation may often exceed the difference between the outstanding balance and the amount payable on the basis of market value. As a result, it is common for the expropriating authority to pay out the mortgagee on the basis of the outstanding balance of principal and interest, although this is more than market value, in order to avoid the costs of obtaining evidence designed to show the market value of the mortgage.

However, where an expropriating authority chooses to pay the outstanding balance of principal and interest to the mortgagee, and where the market value of that security is in fact less than the outstanding balance paid, the expropriating authority is penalizing the mortgagor by paying the outstanding balance and simply deducting 
it from the market value of the land. In these circumstances the mortgagor has nothing to lose by having the market value of the mortgage appraised and then claiming the difference between the market value of and the outstanding balance under the mortgage which has been wrongly paid to the mortgagee. The expropriating authority will then have to pay to the landowner/mortgagor this additional balance, and may well find itself in a position where it is unable to collect the excess from the mortgagee.

As a result, the expropriating authority is to some extent penalized by virtue of the Act's treatment of cost's payable by the expropriating authority upon expropriation. However, given the fundamental policy behind the payment of costs", it would appear that such provisions are in accord with the general principles underlying the new Expropriation Act.

\section{APPLICATION OF BOTH APPROACHES}

The success or failure of either the outstanding balance approach or the market value approach to deal with particular types of security interest can best be examined using examples of particular types of mortgages in particular situations.

\section{A. Changes in Interest Rate}

It has already been shown that the outstanding balance approach does not differentiate between the rate of interest in two different mortgages. In the event that the outstanding balance of principal and interest on each mortgage is the same, the same payment will be received by the mortgagee (assuming that there is sufficient equity in the land expropriated). The market value of each mortgage will vary according to any of a number of criteria already listed. The most commonly encountered factor will be a change in the interest rates so that the rate set out in the mortgage contract no longer reflects the current rate of interest existing at the date of expropriation.

Illustrations 1 and 2 in Appendix D show the different results which will be experienced under each method of valuation.12

In addition to the comparison of changing interest rates, consideration of the mortgage term itself is included. It will be seen that the shorter the time to maturity, the less the difference between the two approaches. Where the mortgage still has 23 years left to run (Illustration 1) the difference caused by a change in interest rates will be significantly larger than the difference where the mortgage matures in three years.

In calculating the effect on valuation of the remaining term of a mortgage, attention should be paid to the provisions of $\mathrm{s} .10$ of The Interest Act, R.S.C. 1970, c. I-18, (Appendix E). In the case of a mortgage to which s. 10 applies, the market value of that mortgage will

11. Alberta Institute of Law Research and Reform, Working Paper on the Principles of Compensation, (1971) at 90.

12. In the British Columbia Law Reform Commission, Report on Expropriation, (1971) at pp 141-148, Professor S.W. Hamilton prepared certain materials to compare the "outstanding balance" approach, and the market value approach. The illustrations in Appendix "D" are based on these examples provided by Professor S.W. Hamilton. 
be affected by the provisions of the section so that the difference between the two approaches will be reduced. However, the one-way application of s. 10 should be noted. Only the mortgagor has the right to pre-pay and redeem after five years, so that in the event of a rise in interest rates the possibility of pre-payment after five years should probably not be taken into account when establishing the market value of the mortgage, as the mortgagor would not usually wish to replace his mortgage.

\section{B. Bonus Mortgages}

Illustrations 3 and 4 in Appendix $\mathrm{D}^{13}$ deal with two types of "bonus mortgage" situations. The first is the situation where the bonus is explicit. A mortgagee lends $\$ 7,832.00$ but receives a mortgage for $\$ 10,000.00$ at $10 \%$ (4\% lower than market rates). The additional sum secured has the effect of raising the real rate of interest on the sum loaned. If the property against which the mortgage is secured were to be expropriated immediately, the mortgagee would receive the full $\$ 10,000.00$ on the outstanding balance approach. On the other hand if the same loan had been secured by a mortgage for the amount of the loan with an interest rate of $14 \%$, reflecting current market rates, the mortgagee would receive only $\$ 7,832.00$. As can be seen from Illustration 3 in Appendix D, the market value approach to this type of mortgage will result in the same compensation being paid to the mortgagee regardless of the method of securing the loan.

Bonus mortgages of the type described above are not as common now as they were in the past. Today the situation is more often the one described in Illustration 4, where the "bonus" is hidden in the whole sale and purchase transaction. The outstanding balance approach will in this case overcompensate the second mortgagee/vendor at the expense of either the mortgagor or the expropriating authority, whereas the market value approach will reflect the financial realities of the sale.

\section{Participation Mortgages}

As already stated, the outstanding balance method will not reflect the additional value of the security that is attributable to the presence of a participation clause in a mortgage.

However, this participatory feature presents no problem when calculating the market value of a mortgagee's security, since the existence of this feature will be taken into account and assessed in view of the financial and accounting records of the mortgagor, the projected success of the mortgagor's venture and other similar variables obtained by the appraiser.

\section{COMPENSATION AND RELIEF WHERE DEFICIENCY}

Occasionally the amount owing on a mortgage will exceed the market value of the land at the date of expropriation, so that the compensation is insufficient to cover not only the mortgagor's own investment in the property but also the full amount of the mortgage 
indebtedness. A typical example is where land is bought at the crest of a boom with a small down payment and the balance secured by one or more mortgages. In respect of the mortgagor's own investment it has been recognized 14 that a purchaser of land assumes certain risks on buying land. If he paid too much for the land, then he must bear his loss if prices fall. The Ontario Law Reform Commission concluded, 15 "Expropriating authorities should not have to protect purchasers from the vicissitudes of the market".

However, what protection should a mortgagor receive with regard to his liability on the covenant to the mortgagee? Under the former expropriation legislation in Alberta, the owner remained liable to the mortgagee on the personal covenant in all those situations where The Judicature Act did not give the owner its protection.

In Ontario, where the balance outstanding on the mortgage must be paid, the legislature provided for two situations where it felt that protection for the owner/mortgagor was warranted. Where the mortgage is a purchase - money mortgage, and where the compensation paid is insufficient to satisfy the mortgage, the owner/mortgagor is relieved of any liability for the deficiency. ${ }^{16}$ Secondly, where the mortgage includes a bonus the owner/mortgagor is relieved of any liability for either the difference between the balance of principal and interest and the compensation available or the amount of bonus, whichever is the smaller sum.17

The Alberta Institute of Law Research and Reform was concerned that the mortgagor receive adequate protection in cases where there was an apparent deficiency. Where the mortgagee is paid on the basis of the market value of the mortgage, two of the important factors in assessing this market value will be the strength or weakness of the security as determined by the value of the land itself, and the enforceability of the personal covenant. Where an individual owns land that is "over-mortgaged", the calculations of market value of the mortgage(s) against that land will reflect the provisions of The Judicature Act, s. 34(17), relating to the unenforceability of the personal covenant, and payment to the mortgagee(s) will be reduced accordingly. Accordingly, there will be few if any cases of deficiency under the market value approach where mortgages granted by individuals are concerned.

Provision is however made in s. 47(2) and (3) of the Alberta Act to deal with deficiencies in two types of situations, one where there is no collateral security and the other where collateral security has been taken by the mortgagee.

14. See British Columbia Law Reform Commission, Report on Expropriation, (1971), at 140. See Ontario Law Reform Commission, The Basis for Compensation on Expropriation, (1967) at 32.

15. See Ontario Law Reform Commission, The Basis for Compensation on Expropriation, (1967) at 32 .

16. However, this would unduly penalize the mortgagee in a falling real estate market where the purchase money mortgage has not been "bonused". The fall in the market may be sufficient to ensure that the mortgagee cannot be satisfied in full, and s. 17(4) (a) will operate to deny the mortgagee's claim to the balance. The Manitoba Act overcomes this particular provision by providing that the balance is to be discharged to the extent that the purchase price exceeded the market value of the land at the date of purchase.

17. The Expropriation Act (Ont.), s. 17(4)(b). 
Section 47(2) discharges the mortgagor from any liability, where there is no collateral security other than the mortgagor's covenant to pay. The Alberta Institute of Law Research and Reform felt that this was the fairest thing to do in view of the fact that the expropriation changes the mortgagor's obligations from one of repayment over time during the term of the mortgage to one where the mortgage debt is immediately due.

Of all the criticism levelled at the provisions of s. 47 , probably the most significant is the criticism relating to the valuation of the personal covenant. An example of the type of problem that may arise is as follows. A mortgage company grants a mortgage upon property that is used as a service station by a large oil company. In making the loan the mortgagee is well aware that the market value of the property itself may not justify the amount of the loan, but this fact is offset by the value of the personal covenant of the borrower. For example, Texaco Canada on a service station site may be able to obtain a loan two or three times the market value of the lands and buildings on the site because the lender would assess the value of the covenant of Texaco very highly. Often in such situations the lender will not have occasion for collateral or other security. It is unlikely that personal guarantees would be required on a mortgage granted by Texaco, and often the property is of such a nature that collateral security on chattels is not appropriate.

In this type of situation the application of s. 47(2) may result in a substantial expense to the expropriating authority. If the "market value of the security" includes, in accordance with the principles enunciated in $s$. 39, the valuation of the personal covenant of the borrower, then the authority that expropriates the Texaco service station may pay substantially more than the market value of the property, simply because the mortgagee has placed a loan which is in in substantial part appraised on the basis of the value of Texaco's covenant, which covenant is perfectly enforceable as a result of s. 35 of The Judicature Act.

Subsection (3) of s. 47 presents a different problem. That subsection provides that the debt is not discharged by payment of compensation where there exists collateral security (other than the personal covenant). The compensation must be based on the market value of the mortgage (s. $40(2)(\mathrm{a})$ ) and will be determined in accordance with the principles already described. However, where the balance of principal and interest owing to the mortgagee exceeds the market value of the mortgage, s. $47(3)$ appears to protect this difference for the mortgagee (subject to the discretion of the Land Compensation Board).

If, however, the principle underlying the removal of the mortgagee's right to recover any deficiency is that the mortgagor should not be prejudiced by the conversion of his obligation to make payments over an extended length of time into a current liability, 18 why should the mortgagor not receive this protection whether there exists collateral security or not. From the mortgagee's point of view, why should a 
prudent lender who agrees to lend an amount equal to two-thirds of the value of certain property (and therefore finds it unnecessary to take collateral security) be placed in a (possibly) worse position than another mortgagee who lends $90 \%$ of the value of property but supports it with collateral security. The Alberta Institute of Law Research and Reform justified the different treatment of mortgages with and without collateral security on the basis that a mortgage supported by collateral security will be more valuable, but this can only be true where the equity of the owner/mortgagor is the same in both situations. In the examples above, where the equity of the owner differs in each case, it is surely impossible to say that the latter mortgage has a greater market value as a result of the collateral security.

\section{DISTURBANCE DAMAGES}

Because security interests are appraised on the basis of their market value in Alberta, there is no requirement for the disturbance provisions found in s. 20(b) and (c) of the Ontario Act (Appendix c). The mortgagor will not require compensation for disturbance at all since the market valuation of the mortgage will take into account such factors as the higher interest rate that he will have to pay on substitute financing. The mortgagee will however require additional compensation for the loss of revenue pending reinvestment of the funds.

In Alberta this additional compensation is payable to the mortgagee by virtue of s. 50 (Appendix B). Three months interest on the amount of the outstanding principal is payable at the interest rate prescribed in the mortgage contract. ${ }^{19}$ This payment is made by the expropriating authority, without any deduction from the amount paid to the owner /mortgagor. However, s. 50 appears to provide payment of this three month's interest "bonus" to the mortgagee regardless of whether the security document requires some prepayment or not. The expropriating authority will be required to pay the bonus even where the mortgage in question permits the mortgagor to prepay the entire balance owing without notice or bonus, thus providing the mortgagee with a "windfall" at the expense of the expropriating authority. One suggested reason for the three-month bonus in all cases is that there will generally be a gap of nearly three months between the registration of the Certificate of Approval and the Proposed Payment, during which time the mortgagee will be without funds. However, in view of the provisions of $s .64(1)$ relating to interest, it would seem that the mortgagee will be entitled to interest during this period "at such rate as the Board considers just" (hopefully the rate of interest in the mortgage itself), so that the possibility of a "windfall" still exists. Since an important reason for adopting the market value approach is to avoid such "windfall" profits, it is suggested that s. 50 (1) should be amended to require payment of three months interest or the value of any notice or bonus for prepayment provided for in the security document, whichever is the lesser, in a manner similar to s. 20(a) of the Ontario Expropriations Act.

19. $c f$. s. 20(a) of The Expropriation Act (Ont.) where the rate is set at $6 \%$ or such rate prescribed by regulation. See also s, 10 of The Interest Act, R.S.C. 1970, C. 1-18. 
Section 50(1) introduces, for the first time, the term "the amount of the outstanding principal".

Is the "outstanding principal" the balance to be paid on the basis of the market value of the mortgage, which would appear more logical given the other valuation provisions already discussed, or to be paid on the basis of the amount owing by the mortgage terms alone, which appears to fit more easily with the words "outstanding principal"? Unfortunately, s. 50(1) does not provide an answer.

Another question is left unanswered by s. 50(1). Is the bonus interest paid under s. 50(1) the only payment that can be required by the mortgagee as the value of the notice or bonus for prepayment? Where the mortgagee has taken collateral security, the compensation under s.47(3) may not discharge the entire debt owed to the mortgagee. Where the contract provides for a greater amount by way of bonus, 20 it would appear that the mortgagor who has given collateral security may be liable for the additional bonus required, subject to the discretion of the Land Compensation Board, which may be able to protect the mortgagor to some extent by its determination of "the balance remaining and the manner in which it is to be repaid."

\section{PARTIAL TAKINGS}

In Ontario, s. 17(6) (Appendix C) provides for a proportionate payment to the mortgagee based on the proportion that the outstanding balance on the mortgage has to the maket value of the whole lands. If the outstanding balance on the mortgage amounts to $60 \%$ of the market value of the land, then upon expropriation of a portion of the land, the mortgagee will receive $60 \%$ of the market value and damages for injurious affection awarded for the portion of the land actually taken.21

The Alberta Institute of Law Research and Reform felt that a formula was not practical for the following reasons:22

\footnotetext{
"Most of the partial takings in Alberta are for a highway or for right of way (as distinguished from a fee simple). The value of the taken land is usually only a fraction of the whole parcel. The mortgage may be well secured and the payments up to date and in that event the whole of the compensation should go to the mortgagor. There may be other circumstances in which fairness requires compensation to be paid in whole or in part to the security holder. We think the best solution is to leave the distribution to the tribunal."
}

The recommendation of the Institute was accepted and incorporated as s. 47(4) (Appendix A), and the Land Compensation Board has been given the authority to determine the market value and make the proper distribution of the compensation.

Section 47(3) gives the Board the power to determine the balance payable on a mortgage where there is collateral security by way of security on other property. Where one of two or more lots covered by a blanket mortgage is expropriated the Board will have to determine

20. See Re Sankey and Township of King (1973) 4 L.C.R. 277, 279.

21. See also The Expropriation Act, R.S.C. 1970, c. 16 (1st Supp.) s. 28(8)(c).

22. Alberta Institute of Law Research and Reform, Working Paper on the Principles of Compensation (1971), at 96. 
the balance owing on the mortgage following payment of compensation. It is at this stage that figures based on both market value and the outstanding balance will be required, and a possible solution to this type of problem is contained in Appendix " $F$ ".

\section{SUMMARY}

Alberta is the only jurisdiction in Canada which adopts the market value approach to the valuation of security interests on expropriation. Up to November of 1978 , no cases have come before The Land Compensation Board (or the Supreme Court of Alberta) which require the determination of the market value of a security interest. Accordingly, there are no decisions to which reference can be made in order to assist lawyers in interpreting the provisions of either s. 47 or s. 50 of The Expropriating Act. It remains to be seen how the legislation will be applied and how it will affect the parties involved in the expropriation, in particular, the owner/mortgagor, the mortgagee and the expropriating authority.

Even before the provisions of the Alberta Act have been applied many mortgagees have expressed concern at this new approach to the valuation of their security interest. In general, mortgagees prefer the outstanding balance approach to the valuing of mortgages. In part, this preference is due to the fact that the mortgagee can anticipate receiving, in cash, the outstanding balance of the money actually advanced on the mortgage, and to the fact that the outstanding balance approach treats the mortgage in a similar manner to the way it is treated on other occasions such as foreclosure or bankruptcy. Most of all however, in circumstances like the present where the Canadian economy has experienced a long period of rising interest rates, awards based on the outstanding balance approach will generally be greater than those based on market value. At the risk of appearing cynical, in times of falling interest rates, mortgagees may well be prepared to forego the benefits of simplicity and other benefits possibly associated with the outstanding balance approach in favour of the market value approach, which, as already seen, will provide the mortgagee with a greater return in those cases where the interest rate on expropriation is lower than the interest rate contained in the mortgage document.

A further complaint raised by mortgagees is that the market value approach does not take into account the fact that many mortgages are paid out prior to their maturity date, usually because the property against which they are secured is sold and a new mortgage or other financing obtained by the purchaser. As a result, mortgagees anticipate repayment of the full outstanding balance by the mortgagor at sometime prior to the actual date of maturity. Again, in periods of rising interest rates, payment upon expropriation of the market value of the mortgage will provide to the mortgagee, a smaller sum than anticipated using the outstanding balance approach.

However, where interest rates are falling, it would be very difficult to maintain this complaint. For every mortgage that is paid out prior to maturity in times of rising interest rates, a far larger proportion will be paid out in advance during periods where the interest rate is falling. Using the market value approach, the mortgagee will generally 
receive a greater sum in times of falling interest rates, so that it would appear that mortgagees would be substantially better off it they were compensated on expropriation on the basis of market value. Furthermore, if mortgagees are concerned by the common practice of payment of the balance outstanding by mortgagors prior to maturity, such a factor should be included in calculating the market value of the mortgage in a similar manner to the taking into account of the actual term of the mortgage (see Appendix D).

There is no doubt that some problems still remain with the market value approach to compensation. However, it is suggested that the potential problems such as insufficiency of data to establish a market value and the problems of the costs of proving the market value of a particular interest either no longer exist or, in the case of costs, are drawbacks that are acceptable given the basic principles of the new Expropriation Act. It is submitted that the market value approach provides a more equitable valuation not only of standard mortgages, but more noticeably of mortgages where there exists some special features which render the outstanding balance approach inappropriate.

Probably the major problem caused by s. 47 relates to the valuation of the personal covenant, where there is insufficient value in the land itself to compensate the mortgage fully, and the effect of collateral security. As far as the problem relating to collateral security is concerned, it would seem appropriate to wait and see how this matter is dealt with by the Land Compensation Board and by the Supreme Court of Alberta before any decision is made in this regard. However, in connection with the personal covenant, a suggestion that might be reviewed is to provide to mortgagors protection on the same basis that it is provided by s. 34(17) of The Judicature Act, so that individuals would receive the protection as provided in s. $47(2)$, whereas corporations would not receive this protection. Since the status (corporate or otherwise) of the borrower is a matter that is already taken into account by mortgagees when they make loans, such considerations could simply be expanded to include the possibility of expropriation of the security interest at the time when the loan is made.

The Alberta Institute of Law Research and Reform concluded,23

". . . that despite some complexity, fairness is best achieved by valuing both the security interest and the "owner's" (mortgagor's or purchaser's) interest separately at market value."

It is submitted that despite the problems outlined above, valuation of security interests at market value does achieve "fairness" not only insofar as the mortgagor and mortgagee are concerned, but also as far as the expropriating authority is concerned to the extent permitted by the principles underlying the new Expropriation Act.

To penalize the expropriating authority is ultimately to penalize the general public whether by way of increased taxes or higher school or utility assessments, so that a system which attempts to overcome individual problems by penalizing the expropriating authority may well not offer the same solution as the system which has now been adopted by The Expropriation Act, namely the separate valuation of security interests at their market value. 
APPENDIX A

EXPROPRIATION ACT, S.A. 1974, c. 27

47. (1) Where the expropriated land is subject to a security interest, the market value of each person having an interest in the land shall be established separately.

(2) Where the amount owing to the security holder is greater than the market value of his interest and there is no collateral security other than the covenant of the purchaser or borrower to pay the amount of the debt, the security interest shall be deemed to be fully paid, discharged and satisfied on payment to the security holder of the market value of the security.

(3) Where the amount owing to the security holder is greater than the market value of his interest and there is collateral security other than the covenant of the purchaser or borrower to pay the amount of the debt, and whether such collateral is by way of security on other property or a guarantee of a third party or otherwise, the compensation shall not fully discharge the debt and the Board shall determine the balance remaining and the manner in which it is to be repaid.

(4) Where the expropriation is of a part of land that is subject to a security interest, the Board shall determine the market value of the expropriated part and shall distribute the compensation between the parties as it considers just in the circumstances.

\section{APPENDIX B}

EXPROPRIATION ACT, S.A. 1974, c. 27

50. (1) Where the expropriated land is subject to a security interest, the expropriating authority shall pay to the security holder three months' interest at the rate described in the security document or, where no rate is prescribed, at the rate that would normally be payable in respect of the security, on the amount of the outstanding principal.

(2) Where the Board makes a determination under section 46, the amount payable in respect of interest under this section to the security holder shall be in the same proportion in relation to the total payment made on account of interest that the land being expropriated and subject to the security interest bears to the entire amount of land subject to the security interest. 
APPENDIX C

EXPROPRIATION ACT, R.S.0. 1974, c. 154

17. (1) In this section, "bonus" means the amount by which the amount secured under a mortgage exceeds the amount actually advanced.

(2) Where land is subject to a security interest,

(a) the value of interest of the security holder shall be determined in accordance with this section and section 20 and not otherwise; and

(b) the market value of the land shall be determined without regard to the interest of the security holder and the amount of such market value plus any damages for injurious affection shall stand in place of the land for the purposes of the security.

(3) Security holders shall be paid the amount of principal and interest outstanding against the security out of the market value of the land and any damages for injurious affection payable in respect of the land subject to the security, in accordance with their priorities, whether or not such principal and interest is due, and subject to subsections 4 and 5 .

(4) Where the land is subject to a mortgage and the amount payable to the mortgagee under subsection 3 is insufficient to satisfy the mortgage in full,

(a) where the mortgage is a purchase-money mortgage, the mortgage shall be deemed to be fully paid, satisfied and discharged for all purposes; and

(b) where the mortgage is not a purchase-money mortgage and includes a bonus,

(i) the amount by which the amount payable to the mortgagee under subsection 3 is insufficient to pay the amount remaining unpaid under the mortgage, or

(ii) the amount of the bonus,

whichever is the lesser, shall be deemed to be fully paid and satisfied for all purposes.

(5) No amount shall be paid in respect of a bonus until all security holders have been paid all amounts payable other than any bonus.

(6) Where land held as security is expropriated in part or is injuriously affected, a security holder is entitled to be paid to the extent possible in accordance with his priority, out of the market value portion of the compensation and any damages for injurious affection therefor, as the case may be, a sum that is in the same ratio to such portion of the compensation and damages as the balance outstanding on the security at the date of the expropriation or injurious affection is to the 
market value of the entire land, provided however that the sum so determined shall be reduced by the amount of any payments made to the security holder by the owner after the date of expropriation or injurious affection. $1968-69$, c. 36, s. 17.

20 . Where a statutory authority prepays a mortgage in whole or in part, the statutory authority,

(a) shall pay to the mortgagee a bonus in respect of the prepayment amounting to,

(i) three months interest on the amount of principal prepaid at the rate of 6 per cent a year or at such other rate as is prescribed by the Lieutenant Governor in Council by regulation, or

(ii) the value of any notice or bonus for prepayment provided for in the mortgage, whichever is the lesser;

(b) shall pay to the mortgagee where,

(i) the prevailing interest rate for an equivalent investment is lower than the rate under the mortgage, and

(ii) there is no provision in the mortgage permitting prepayment at the date of the expropriation,

an amount to compensate for difference in the interest rates for the period for which the amount of principal prepaid has been advanced, not to exceed five years; and

(c) shall pay to the mortgagor whose interest is expropriated an amount to compensate for any loss incurred by reason of a difference in the interest rates during the period for which the payment of principal provided for in the mortgage has been advanced, but such difference shall not be calculated on a new interest rate any greater than the prevailing interest rate for an equivalent mortgage. 1968-69, c. 36, s. 20. 


\section{APPENDIX D \\ MORTGAGE VALUATION UNDER EACH APPROACH}

(Based on materials prepared by Professor S.W. Hamilton for B.C. Law Reform Commission)

The following illustrations are presented to indicate the difference which would exist under the two approaches. (These examples are not intended to reflect current market conditions and ignore disturbance claims.)

Basic Data

Original mortgage loan $\ldots \ldots \ldots \ldots \ldots \ldots \ldots \$ 10,000$

Amortization term ................25 years

Contract interest rate .............8 per cent compounded semiannually

Monthly payments .................. \$76.32

Expropriation occurs at the time of the 24th payment.

\section{Illustration 1}

No Five-Year Call Clause

(a) Rise in Interest rates

(i) Outstanding Balance Approach

Current mortgage rates 10 per cent compounded semiannually.

Outstanding Balance $=\$ 9,721.78$, which is the present value of the remaining 276 payments of $\$ 76.32$ discounted at 8 per cent semiannually.

If the mortgagee reinvested $\$ 9,721.78$ for 23 years at 10 per cent semiannually (current rate), he would receive a monthly annuity of $\$ 88.69$. Hence he is made better off by $\$ 12.37$ per month for 276 months.

(ii) Market Value Approach

Current rates for loans of similar risk is 10 per cent compounded semiannually.

Market Value $=\$ 8,323.31$, which is the present value of the remaining 276 payments of $\$ 76.32$ discounted at 10 per cent semiannually.

If the mortgagee reinvested $\$ 8,323.31$ for 23 years at 10 per cent semiannually, he would receive a montly annuity of $\$ 76.32$, the same as before expropriation.

(b) Fall in Interest Rates

(i) Outstanding Balance Approach

Current interest rates for loan of similar risk is 6 per cent compounded semiannually.

Outstanding Balance $=\$ 9,721.78$ (same as Illustration 1 (a)(i)

If the mortgagee reinvested $\$ 9,721.78$ for 23 years at 6 per cent semiannually, he would receive a montly annuity of $\$ 64.49$. Hence he is worse off by $\$ 11.83$ per month for 276 months.

(ii) Market Value Approach

Current rates for loans of similar risk is 6 per cent compounded semiannually.

Market Value $=\$ 11,530.43$ 
If the mortgagee reinvests $\$ 11,530.43$ for 23 years at 6 per cent semiannually, he will receive a montly annuity of $\$ 76.32$, the same as before expropriation.

\section{Illustration 2}

Five-Year Call Clause

(c) Rise in Interest Rates

(i) Outstanding Balance Approach

Current interest rates for loans of similar risk is 10 per cent semiannually.

Outstanding Balance $=\$ 9,721.78$ (same as Illustration 1 (a)(i))

The five-year clause has no impact if the award is based on the outstanding balance.

(ii) Market Value Approach

Current interest rates for loans of similar risk is 10 per cent semiannually.

Market Value $=\$ 9,237.75$.

The award is greater than in Illustration 1(a)(ii) since in the absence of expropriation, the mortgagee had a claim to receive $\$ 76.32$ for 60 months plus the outstanding balance $(\$ 9,213.50)$ due at the end of the 60th month. If the investor were to reinvest the $\$ 9,237.75$ for 23 years with a three-year call, he would receive $\$ 76.32$ per month plus $\$ 9,213.50$ at the end of three years, exactly his position before expropriation. In practice, the mortgagee would likely reinvest with a new five-year call, not a three-year call, and require montly payments to fully amortize the mortgage in 25 years.

(d) Fall in Interest Rates

(i) Outstanding Balance Approach

Current interest rates for mortgages of similar risk is 6 per cent compounded semiannually, award based on outstanding balance.

Outstanding Balance $=\$ 9,721.78$ (same as Illustrations 1 (a)(i) and 1 (b)(i)).

(ii) Market Value Approach

Current interest rates for mortgages of similar risk is 6 per cent compounded semiannually.

Market Value $=\$ 10,237.04$

If the mortgagee were to reinvest $\$ 10,237.04$ for 23 years at 6 per cent semiannually with a three-year call he would receive $\$ 76.32$ per month for 36 months plus $\$ 9,213.50$ at the end of three years. 
Summary of Illustrations $1 \& 2$

\begin{tabular}{|c|c|c|c|c|c|}
\hline & & $\underset{\text { (Per Cent) }}{\text { Current Rate }}$ & $\begin{array}{l}\text { Outstand- } \\
\text { ing Balance }\end{array}$ & $\begin{array}{c}\text { Market } \\
\text { Value }\end{array}$ & Difference \\
\hline 1 & No call clause & $\begin{array}{r}10 \\
6 \\
8\end{array}$ & $\begin{array}{r}\$ 9,721.78 \\
9,721.78 \\
9,721.78\end{array}$ & $\begin{array}{r}8,323.31 \\
11,530.43 \\
9,721.78\end{array}$ & $\begin{array}{r}\$ 1,398.47 \\
-1,808.65 \\
\text { Nil }\end{array}$ \\
\hline & Five-year call & $\begin{array}{r}10 \\
6 \\
8\end{array}$ & $\begin{array}{r}\$ 9,721.78 \\
9,721.78 \\
9,721.78\end{array}$ & $\begin{array}{r}\$ 9,237.75 \\
10,237.04 \\
9,721.78\end{array}$ & $\begin{array}{r}484.03 \\
-515.26 \\
\text { Nil }\end{array}$ \\
\hline
\end{tabular}

N.B. If interest rates remain constant, either method of valuation give the same answer.

\section{BONUS AND DISCOUNT MORTGAGES}

Illustration 3.

Consider the following case which arises quite commonly in the market but not in the form which is presented below. A borrower obtains a cash advance of $\$ 7,832.00$ to be secured with a mortgage. The borrower is offered two alternative repayment plans. The first is to promise to repay $\$ 7,832.00$ at 14 per cent compounded semiannually over 20 years with monthly payments; the second is to promise to repay $\$ 10,000$ at 10 per cent compounded semiannually over 20 years with monthly payments. In either case the monthly payments are $\$ 95.17$ for 240 months.

Assume that two years later the property supporting the mortgage is expropriated and that the current mortgage rate for this risk class of mortgage is now 16 per cent compounded semiannually. Four possible awards might be considered for the mortgagee -

(a) Award based on the outstanding balance where the borrower had selected the first alternative.

Award $=\$ 7,657$, which is the present value of the 216 remaining monthly payments of $\$ 95.17$ discounted at 14 per cent compounded semiannually.

(b) Award based on the outstanding balance where the borrower had selected the second alternative.

Award $=\$ 9,643$, which is the present value of the 216 remaining monthly payments of $\$ 95.17$ discounted at 10 per cent compounded semiannually.

(c) Award based on the market value given the first alternative was selected.

Award $=\$ 6,910$, which is the present value of the 216 remaining monthly payments of $\$ 95.17$ discounted at 16 per cent compounded semiannually.

(d) Award based on market value given the second alternative was selected.

Award $=\$ 6,910$, which again is the present value of the 216 remaining monthly payments of $\$ 95.17$ discounted at 16 per cent compounded semiannually. 
Summary of Illustration 3

$\begin{array}{lcc} & \text { Straight Mortgage } & \text { Bonus Mortgage } \\ \text { Outstanding balance } & \$ 7,657 & \$ 9,643 \\ \text { Market Value } & 6,910 & 6,910\end{array}$

Using the market value as a basis of compensation, the mortgagee receives the same award independent of the form in which the mortgage is written while using the outstanding balance as a basis of compensation, a difference of $\$ 1,986$ exists due solely to the form in which the mortgage is written.

Illustration 4

As previously mentioned, bonus mortgages seldom arise in the form presented above. The situation arises in a more subtle manner. Assume a vendor is selling a home subject to an existing first mortgage of $\$ 20,000$. The vendor is offerning the home for $\$ 33,000$ with $\$ 3,000$ down payment and a vendor second mortgage of $\$ 10,000$ at 10 per cent compounded semiannually with a 20 -year term. Alternatively, the vendor is prepared to sell for $\$ 30,832$ cash to the existing first mortgage. This is the common manner in which a bonused mortgage arises. If the second mortgage were granted and the current rate for such a mortgage was 14 per cent compounded semiannually, the vendor could sell the second mortgage and realize $\$ 7,832$ cash plus the $\$ 3,000$ down payment. Hence his willingness to accept $\$ 10,832$ cash to the existing first mortgage.

\section{APPORTIONMENT ON PARTIAL TAKING \\ Illustration 5}

A purchases two adjoining lots of bare land in the City of Edmonton which he plans to hold for redevelopment. The lots are identical in value and in their future potential. The total purchase price of $\$ 100$, $000(\$ 50,000$ per lot) is financed in part by a loan for $\$ 80,000$ secured by a mortgage to $\mathrm{B}$. Trust Company covering both lots. The interest rate on the mortgage is $8 \%$ and no other security is given.

Two years later the City of Edmonton expropriates one of the lots and at the date of expropriation the balance outstanding on the mortgage is $\$ 76,000$. However, interest rates on similar loans have now risen to $12 \%$.

The first step (s. $47(1)$ ) is to value the mortgage separately at its market value. Because of the $4 \%$ rise in interest rates, the market value of the mortgage will be less than the outstanding balance, say, $\$ 60,000$. Since half of the land comprising the security has been expropriated, half of the market value of the mortgage is payable by the expropriating authority. Accordingly, the City of Edmonton will pay B. Trust Company $\$ 30,000$ (plus presumably one-half the bonus payable under s. 50(1) ). This would release A of any liability to B. Trust Company arising out of the security on the first lot, and the second lot which is still owned by A would now be subject to a mortgage for $\$ 38,000$ (one half of the balance outstanding, $\$ 76,000$ ).

In the event that $A$ and $B$. Trust Company cannot agree on what the montly payments will now be, application can be made under $s$. $47(3)$ to the Land Compensation Board to set these payments. 


\section{APPENDIX E}

INTEREST ACT, R.S.C. 1970, c. I-18

10. (1) Whenever any principal money or interest secured by mortgage of real estate is not, under the terms of the mortgage, payable until a time more than five years after the date of the mortgage, then, if at any time after the expiration of such five years, any person liable to pay or entitled to redeem the mortgage tenders or pays, to the person entitled to receive the money, the amount due for principal money and interest to the time of the payment, as calculated under sections 6 to 9 , together with three months further interst in lieu of notice, no further interest shall be chargeable, payable or recoverable at any time thereafter on the principal money or interest due under the mortgage.

(2) Nothing in this section applies to any mortgage upon real estate given by a joint stock company or other corporation, nor to any debenture issued by any such company or corporation, for the payment of which security has been given by way of mortgage on real estate. R.S., c. 156, s. 10. 